\title{
Pronounced interannual variability in tropical South Pacific temperatures during Heinrich Stadial 1
}

\author{
Thomas Felis ${ }^{1}$, Ute Merkel ${ }^{1}$, Ryuji Asami ${ }^{2}$, Pierre Deschamps ${ }^{3}$, Ed C. Hathorne ${ }^{1, \dagger}$, Martin Kölling ${ }^{1}$, \\ Edouard Bard ${ }^{3}$, Guy Cabioch ${ }^{4}+$, Nicolas Durand ${ }^{3}$, Matthias Prange ${ }^{1}$, Michael Schulz ${ }^{1}$, \\ Sri Yudawati Cahyarini ${ }^{5} \&$ Miriam Pfeiffer 6
}

The early last glacial termination was characterized by intense North Atlantic cooling and weak overturning circulation. This interval between 18,000 and 14,600 years ago, known as Heinrich Stadial 1, was accompanied by a disruption of global climate and has been suggested as a key factor for the termination. However, the response of interannual climate variability in the tropical Pacific (El Niño-Southern Oscillation) to Heinrich Stadial 1 is poorly understood. Here we use $\mathrm{Sr} / \mathrm{Ca}$ in a fossil Tahiti coral to reconstruct tropical South Pacific sea surface temperature around 15,000 years ago at monthly resolution. Unlike today, interannual South Pacific sea surface temperature variability at typical El Niño-Southern Oscillation periods was pronounced at Tahiti. Our results indicate that the El Niño-Southern Oscillation was active during Heinrich Stadial 1, consistent with climate model simulations of enhanced El Niño-Southern Oscillation variability at that time. Furthermore, a greater El Niño-Southern Oscillation influence in the South Pacific during Heinrich Stadial 1 is suggested, resulting from a southward expansion or shift of El Niño-Southern Oscillation sea surface temperature anomalies.

\footnotetext{
${ }^{1}$ MARUM-Center for Marine Environmental Sciences, University of Bremen, 28359 Bremen, Germany. ${ }^{2}$ Trans-disciplinary Research Organization for Subtropical Island Studies (TRO-SIS), University of the Ryukyus, Okinawa 903-0213, Japan. ${ }^{3}$ CEREGE, UMR 6635, Aix-Marseille Universités, CNRS, IRD, Collège de France, 13545 Aix-en-Provence, France. ${ }^{4}$ IPSL, LOCEAN, UPMC, CNRS, IRD, MNHN, Centre Institut de Recherche pour le Développement, 93143 Bondy, France. ${ }^{5}$ Research Centre for Geotechnology, Indonesian Institute of Sciences (LIPI), Bandung 40135, Indonesia. ${ }^{6}$ Geological Institute, RWTH Aachen University, 52056 Aachen, Germany. †Present address: GEOMAR | Helmholtz Centre for Ocean Research, 24148 Kiel, Germany. tDeceased. Correspondence and requests for materials should be addressed to T.F. (email: tfelis@marum.de).
} 
$\mathrm{N}$ ear the onset of the last glacial termination, a massive discharge of icebergs marked the cold Heinrich Stadial 1 (HS1) interval in the North Atlantic region that was accompanied by a weaker Atlantic meridional overturning circulation $(\mathrm{AMOC})^{1-3}$. The extreme climate conditions during this interval were communicated throughout the Northern Hemisphere into the tropics through changes in ocean and atmospheric circulation, resulting in a weakening of the Asian Monsoon and a southward shift of the Intertropical convergence zone ${ }^{3}$. These changes were accompanied by a southward shift of the Southern Hemisphere westerlies, which has been suggested as crucial in driving the rise of atmospheric $\mathrm{CO}_{2}$ during the last termination ${ }^{3,4}$. The impact of HS1 on interannual climate variability in the tropical Pacific, however, is poorly known, largely because of the low temporal resolution of available proxy records. However, a better knowledge of the glacial dynamics of the dominant mode of Pacific atmosphere-ocean variability on interannual timescales, the El Niño-Southern Oscillation (ENSO), is critical regarding its dramatic global climate and socioeconomic impacts and difficult to predict behaviour under future climate change $\mathrm{e}^{5,6}$. Moreover, HS1 provides an opportunity to validate climate models under extreme boundary conditions of the past, which can help to constrain more reliable projections of future ENSO variability 5,6 .

Reconstructions from tropical Pacific sediments indicate an ambiguous pattern of ENSO dynamics with respect to HS1 (refs $7,8)$. This may reflect difficulties associated with the interpretation of ENSO variability from records that do not resolve interannual variability, or different aspects or timescales of ENSO captured by the individual reconstructions. In contrast, seasonally resolved records from fossil shallow-water corals were successfully used to reconstruct interannual ENSO variability in the tropical Pacific during the last glacial ${ }^{9}$, but represent short intervals older than 38,000 years only. A few coral records are available for intervals of the last glacial termination ${ }^{10-14}$, but are too short to document significant interannual ENSO variability. In modern observations, ENSO variability is described by monitoring tropical Pacific sea surface temperature $(\mathrm{SST})^{15}$. However, proxy records of interannual tropical Pacific SST variability during HS1 do not exist, largely because fossil reefs of that age are difficult to access as global sea level stood some $100 \mathrm{~m}$ lower than today ${ }^{16}$.

Here we present results from a fossil coral recovered by Integrated Ocean Drilling Program (IODP) Expedition 310 in the central tropical South Pacific $113 \mathrm{~m}$ below present sea level ${ }^{17}$. In the skeleton of this coral, we analyse the Sr/Ca temperature proxy at monthly resolution representing an interval of more than 2 decades during HS1. We show that significant interannual SST variability at typical ENSO periods occurred at Tahiti, which is different from today. Our results suggest a greater ENSO influence in the South Pacific at that time, and indicate that ENSO was operating and that interannual ENSO variability was pronounced during HS1. Our results are consistent with climate model simulations that indicate enhanced ENSO variability during this interval of the last glacial termination, which was characterized by extreme cold conditions in the North Atlantic and a weakening of the AMOC.

\section{Results}

Coral preservation and age. Fossil Porites coral (310-M0024A11R-2W 1-62) was recovered from $21 \mathrm{~m}$ below sea floor at the outer fore-reef slope off Tiarei on the north side of Tahiti island (French Polynesia, IODP Hole M0024A, $149^{\circ} 24.2358^{\prime}$ W, 17²9.2918' S; Fig. 1$)^{17}$. X-radiography of the slabbed coral core reveals skeletal density banding and a continuous upward growth at a rate of $\sim 2.0 \mathrm{~cm}$ per year, consistent with the $60-\mathrm{cm}$-high colony being drilled in growth position. Powder X-ray diffraction, petrographic thin sections, scanning electron microscopy (SEM) and micronscale laser ablation (LA)-ICP-MS analyses indicate that the aragonitic coral skeleton is well preserved (Supplementary Methods and Supplementary Figs S1-S7). Two highly consistent U-Th ages indicate that the coral grew $14.994 \pm 0.025$ thousand years before the present (kyr BP; 'present' is defined as AD 1950) ${ }^{18}$ (see Methods and Supplementary Table S1), a few centuries before the onset of the Bølling warming at $14.642 \mathrm{kyr} \mathrm{BP}$ (maximum counting error $0.186 \mathrm{kyr})^{19}$ that followed the cold HS1 in the North Atlantic (Fig. 2). Three modern Tahiti Porites corals were used as a benchmark with respect to seasonality and mean conditions. Our modern coral (TAH-95) drilled in June 1995 at 4-5m water depth on the forereef slope of the Papeete barrier reef (Faré Uté) on the north side of Tahiti provides a short record for proxy calibration with local SST (see Methods and Supplementary Fig. S8). The two longer records of modern corals from the Teahupoo (TH1) and Vairao (TH2) lagoons in southeastern Tahiti ${ }^{20}$ were used as a benchmark with respect to interannual variability.

Coral Sr/Ca record. Our $15.0 \mathrm{kyr}$ BP Tahiti coral provides an ultrahigh-resolution snapshot of tropical Pacific climate variability during HS1. In the western tropical Pacific and Antarctica, this interval was characterized by deglacial warming ${ }^{21,22}$, whereas the conditions that prevailed in the eastern tropical Pacific are still debated $^{23,24}$ (Fig. 2 and Supplementary Fig. S9). The Sr/Ca ratios in coral skeletons are an established proxy for SST variability ${ }^{10,11,25-28}$. Here we present a monthly resolved $\mathrm{Sr} / \mathrm{Ca}$-based SST reconstruction for a time window of 22 years generated from our HS1 coral (Fig. 3a), which is exceptionally long given the corals' age and recovery method. The reconstruction shows clear annual cycles indicating SST seasonality with an amplitude that is not different from today (Fig. 3a; Supplementary Fig. S10). Furthermore, a lowering of mean SST relative to today is suggested (Supplementary Fig. S9). a

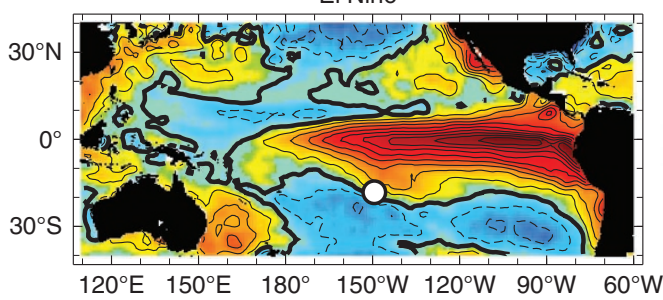

b

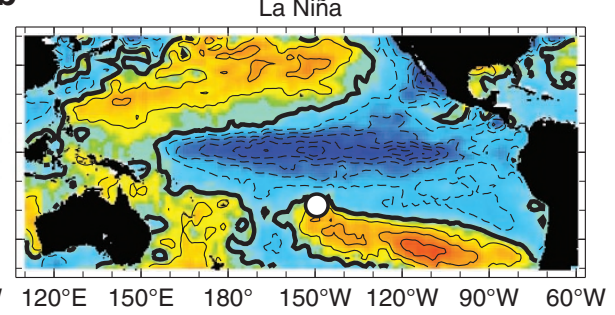

$$
\begin{array}{ccccccccccc}
-5 & -4 & -3 & -2 & -1 & 0 & 1 & 2 & 3 & 4 & 5 \\
\multicolumn{1}{c}{\text { Sea-surface temperature anomaly }\left({ }^{\circ} \mathrm{C}\right)}
\end{array}
$$

Figure 1 | Maps of the Pacific Ocean. Composite maps of sea-surface temperature anomalies ${ }^{35}$ for moderate to strong (a) El Niño and (b) La Niña events during the period 1982-2008 (November-February). The location of Tahiti (and Integrated Ocean Drilling Program site M0024) in the tropical South Pacific is indicated by the white dot 


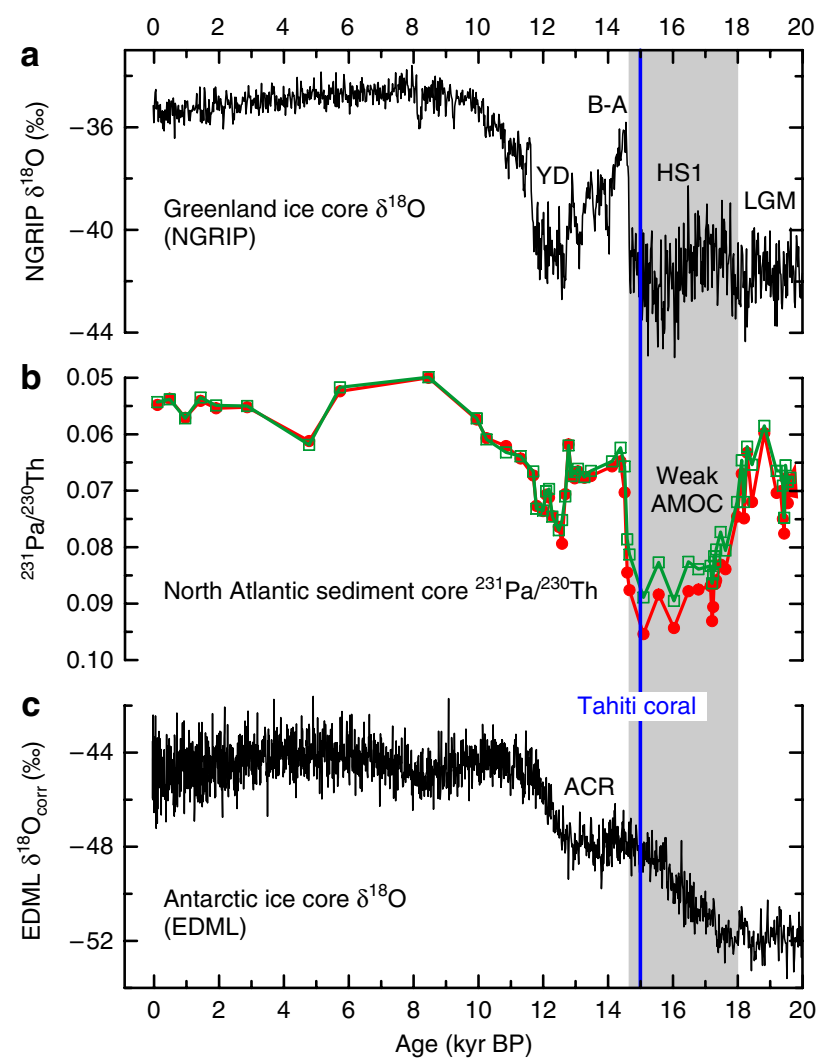

Figure 2 | Tahiti coral age and North Atlantic and Antarctic climate reconstructions. (a) Greenland ice core $\delta^{18} \mathrm{O}$ (North Greenland Ice Core Project, NGRIP), an air temperature proxy ${ }^{58}$ (GICC05 age scale ${ }^{19}$ relative to AD 1950). Younger Dryas (YD), Bølling-Allerød (B-A), Heinrich Stadial 1 (HS1, grey bar) (as defined in refs 3,59) and late Last Glacial Maximum (LGM) are indicated. (b) North Atlantic sediment core ${ }^{231} \mathrm{~Pa} /{ }^{230} \mathrm{Th}$, an AMOC strength proxy ${ }^{2}$. (c) Antarctic ice core $\delta^{18} \mathrm{O}$ (EPICA Dronning Maud Land, EDML), an air temperature proxy ${ }^{21}$. Antarctic Cold Reversal (ACR) is indicated. The blue bar indicates the $U$-series age of the fossil Tahiti coral. For clarity, bar width represents twice the dating uncertainty. All ages are given in thousand years before present (kyr BP), where 'present' refers to AD 1950.

The most striking result, however, is that spectral analysis reveals significant variance in the SST reconstruction at interannual periods of 2 and 5 years (Fig. 3a). This finding indicates that pronounced interannual variability at typical ENSO periods occurred in tropical South Pacific SST at 15.0 kyr BP. Our result strongly suggests that ENSO was active during HS1, and had an influence on interannual SST variability around Tahiti. Interestingly, the ENSO influence on Tahiti SST is weak and non-stationary at present. This results from the fact that, today, Tahiti is located near the nodal line of ENSOinduced SST anomalies in the Pacific, resulting in anomalies close to zero and of varying sign during both El Niño and La Niña events (Fig. 1). Consequently, modern Tahiti coral Sr/Ca-based SST records ${ }^{20}$ do not reveal significant variance at typical ENSO periods (Fig. 3b), in contrast to our HS1 coral Sr/Ca record.

Coral $\delta^{18} \mathrm{O}$ record. The HS1 coral $\delta^{18} \mathrm{O}$ record reveals only weak variance at ENSO periods (Fig. $3 \mathrm{~d}$ ). This is not necessarily in conflict with the $\mathrm{Sr} / \mathrm{Ca}$ results as $\delta^{18} \mathrm{O}$ reflects variations in both temperature and $\delta^{18} \mathrm{O}_{\text {seawater }}$, which is closely related to salinity. Modern coral $\delta^{18} \mathrm{O}$ records from the Tahiti region reveal significant variance at ENSO periods of 2-5 years, although the ENSO signal is not well pronounced $^{20,29}$ (Fig. 3e). This $\delta^{18} \mathrm{O}$ ENSO signal results from the northeastward (southwestward) shift of the South Pacific Convergence Zone (SPCZ) of enhanced precipitation and the westward (eastward) movement of the southwestern tropical Pacific salinity front during El Niño (La Niña) events ${ }^{30}$. The HS1 coral lived in a water depth of $\leq 10 \mathrm{~m}$, more likely in $\leq 5 \mathrm{~m}$ (ref. 18), similar to our modern Tahiti corals. Consequently, less variance at ENSO periods relative to today in the $\mathrm{HS} 1$ coral $\delta^{18} \mathrm{O}$ record can be interpreted as a change in the influence of the SPCZ and/or the salinity front on Tahiti $\delta^{18} \mathrm{O}_{\text {seawater }}$ during HS1.

\section{Discussion}

$\mathrm{Sr} / \mathrm{Ca}$ records of three modern Tahiti Porites corals indicate an annual SST cycle varying from 2.2 to $3.2^{\circ} \mathrm{C}$, satisfactorily documenting the observed annual cycle of $2.6^{\circ} \mathrm{C}$ (ref. 31 ). This is consistent with results from other locations, showing that the seasonal amplitude between colonies is reproducible ${ }^{27}$. We therefore consider our result of an annual SST cycle of $2.7^{\circ} \mathrm{C}$ at $15.0 \mathrm{kyr}$ $\mathrm{BP}$, which is similar to today, as robust (Supplementary Fig. S10). Our estimates of a reduction in mean SST by $3.5^{\circ} \mathrm{C}$ relative to today, using our seasonal Tahiti coral Sr/Ca-SST relationship or by only $2.4^{\circ} \mathrm{C}$, using a possibly more suitable relationship for mean Indo-Pacific SST changes ${ }^{32}$, however, have relatively large uncertainties. As commonly observed at various locations $27,28,33$, between-colony offsets in mean $\mathrm{Sr} / \mathrm{Ca}$ are evident among the modern Tahiti corals (Supplementary Methods and Supplementary Fig. S9). Taking into account the error induced by these offsets ${ }^{33}$ results in estimates of $3.5 \pm 2.8^{\circ} \mathrm{C}$ or $2.4 \pm 2.0^{\circ} \mathrm{C}$ for the cooling at $15.0 \mathrm{kyr} \mathrm{BP}$, depending on the applied coral Sr/Ca-SST relationship. Furthermore, correcting for potential changes in seawater $\mathrm{Sr} / \mathrm{Ca}$ on glacial-interglacial timescales ${ }^{34}$ leads to smaller cooling estimates, partly in agreement with foraminiferal $\mathrm{Mg} / \mathrm{Ca}$ and alkenone SST reconstructions from the equatorial Pacific ${ }^{22-24}$, but adds additional uncertainties. Clearly, Sr/Ca records from more than one coral would be necessary ${ }^{33}$ to robustly estimate mean Tahiti SST at 15.0 kyr BP.

It is important to note that our major result, the stronger than modern ENSO signal in Tahiti SST during HS1 (Fig. 3a,b), does not necessarily mean that the interannual variability of the entire ENSO phenomenon was stronger at that time, as the difference can be explained by a shift in the nodal line of ENSO-induced SST anomalies relative to Tahiti (Fig. 1). Our results imply Tahiti was located permanently either in the region of positive or of negative SST anomalies during El Niño events, in the time window represented by the HS1 coral. We surmise that a southwestward shift of the nodal line rather than a northeastward shift is more likely, which would have placed Tahiti in the region of positive SST anomalies during El Niño events. This claim is based on four high-amplitude interannual warm events (anomalies $\geq 1^{\circ} \mathrm{C}$ ) in the HS1 SST reconstruction (Fig. 3a), with the most prominent event $\left(\sim 1.5^{\circ} \mathrm{C}\right)$ of two years duration being supported by the U/Ca SST proxy (Supplementary Methods and Supplementary Fig. S11). Such high SST amplitudes are characteristic for modern El Niño events in the equatorial Pacific (Fig. 3c), whereas the influence and amplitude of ENSO in the subtropical southwestern Pacific is much weaker (Fig. 1). Moreover, the standard deviation of reconstructed Tahiti monthly SST anomalies in the 2-7 year ENSO band for HS1 is 28\% higher than the modern case, which is similar to that observed $\sim 10^{\circ}$ further north today ${ }^{35}$. However, we note that our reconstructed difference in ENSO variability is not inconsistent with long-term changes in ENSO behaviour observed in unforced climate model simulations ${ }^{36}$. Nevertheless, our results indicate a greater influence of interannual ENSO variability on tropical South Pacific SST during HS1, and suggest a southward expansion or shift of ENSO SST anomalies at that time.

The weaker than modern ENSO signal in Tahiti coral $\delta^{18} \mathrm{O}$ during HS1 (Fig. 3d,e) along with the stronger than modern ENSO 

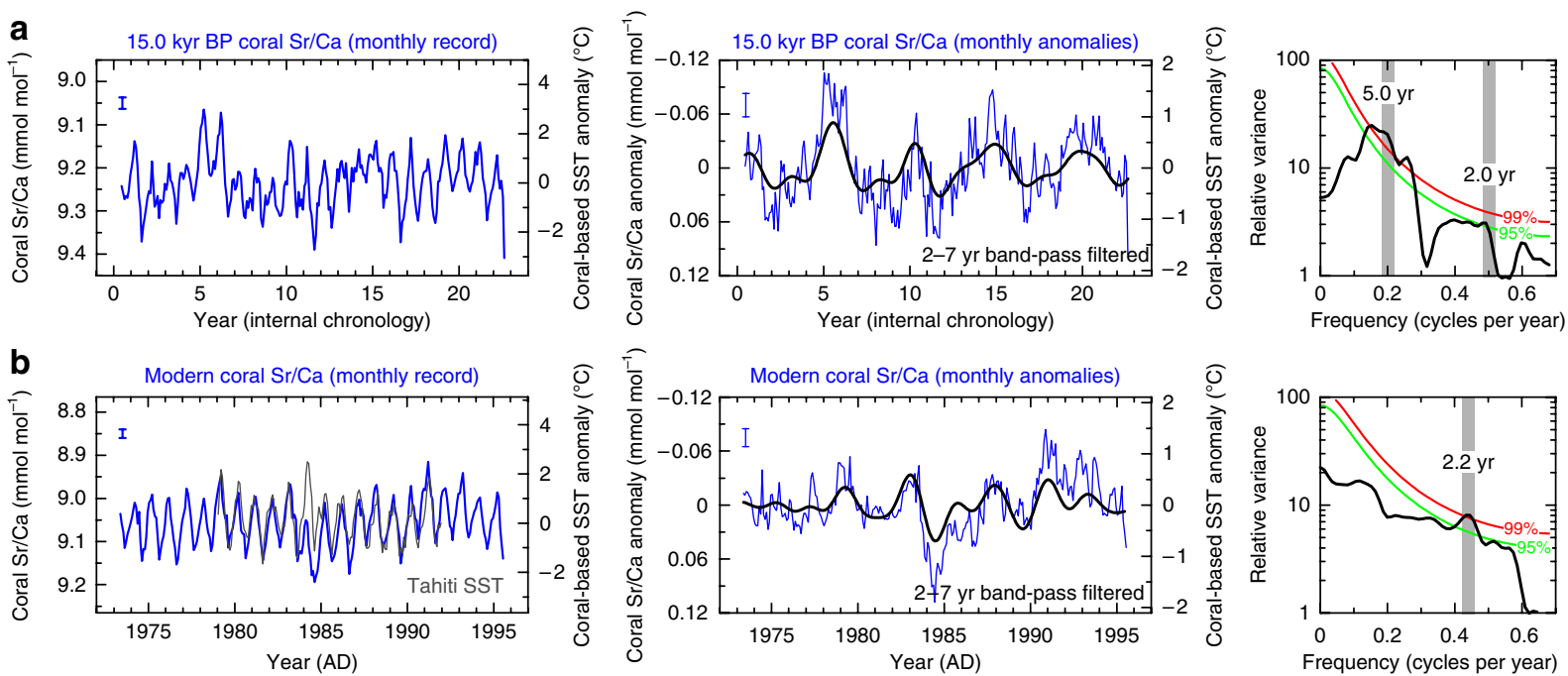

C
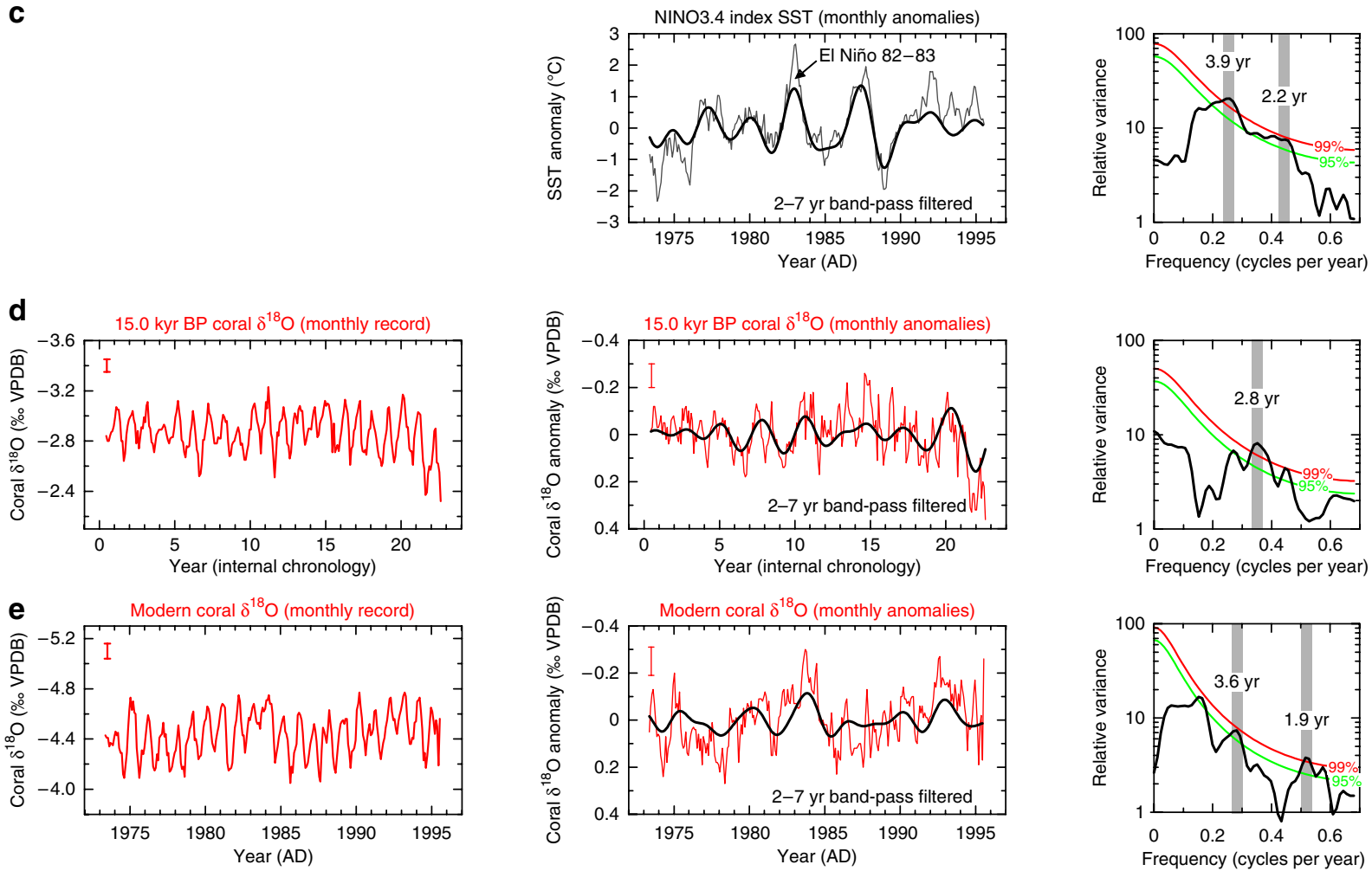

Figure $\mathbf{3}$ | Monthly Sr/Ca and $\boldsymbol{\delta}^{\mathbf{1 8}} \mathbf{O}$ records of Tahiti Porites corals. Monthly coral Sr/Ca records (left panel), 2-7 year Gaussian band-pass filtering of monthly anomaly records (middle panel) and multitaper method spectral analysis (significance relative to a red noise null hypothesis determined with the robust method of noise background estimation 60 ; number of tapers, 3; bandwidth parameter, 2; 95 and $99 \%$ confidence levels indicated; significant spectral peaks labelled) of detrended and normalized monthly anomaly records (right panel) for (a) a Heinrich Stadial 1 coral (15.0 kyr BP) and (b) a modern coral ${ }^{20}$ (average record of cores TH1 and TH2 drilled from two individual colonies). Local Tahiti SST is available from 1979-1991 (ref. 31). There is a limitation of coral Sr/Ca in recording the very high SST of 1984. Coral-based SST anomalies (respective mean was subtracted), using our seasonal Tahiti coral Sr/Ca-SST relationship of $0.057 \mathrm{mmol} \mathrm{mol}^{-1}$ per $1^{\circ} \mathrm{C}$ are shown. (c) Monthly NINO3.4 index ${ }^{35}$ (SST anomalies in the central equatorial Pacific: $\left.170^{\circ}-120^{\circ} \mathrm{W}, 5^{\circ} \mathrm{N}-5^{\circ} \mathrm{S}\right)$ and corresponding band-pass filtering and spectral analysis. (d,e) As in $(\mathbf{a}, \mathbf{b})$, but for monthly coral $\delta^{18} \mathrm{O}$ records. The age of the fossil coral is given in thousand years before present (kyr BP), where 'present' refers to AD 1950.

signal in coral Sr/Ca (Fig. 3a,b) implies coherent SST and salinity variations on ENSO timescales during HS1, as the SST variations inferred from $\mathrm{Sr} / \mathrm{Ca}$ also affect $\delta^{18} \mathrm{O}$, with positive Tahiti SST anomalies being accompanied by positive salinity anomalies during El Niño events at that time. Our findings suggest that, over the time window represented by the HS1 coral, the effect of the SPCZ and/or the southwestern tropical Pacific salinity front on Tahiti salinity was stronger than today on ENSO timescales, probably indicating a slight displacement and/or intensification of these atmospheric and/or oceanic features. However, we emphasize that we consider the stronger than modern ENSO signal in Tahiti coral $\mathrm{Sr} / \mathrm{Ca}$-based SST during HS1 as our most robust finding.

As our record is currently unique for interannual tropical Pacific SST variability during HS1, we utilize the only available study of ENSO behaviour during HS1 performed with a comprehensive climate model (CCSM3 $)^{37}$. We note that shortcomings of CCSM3 

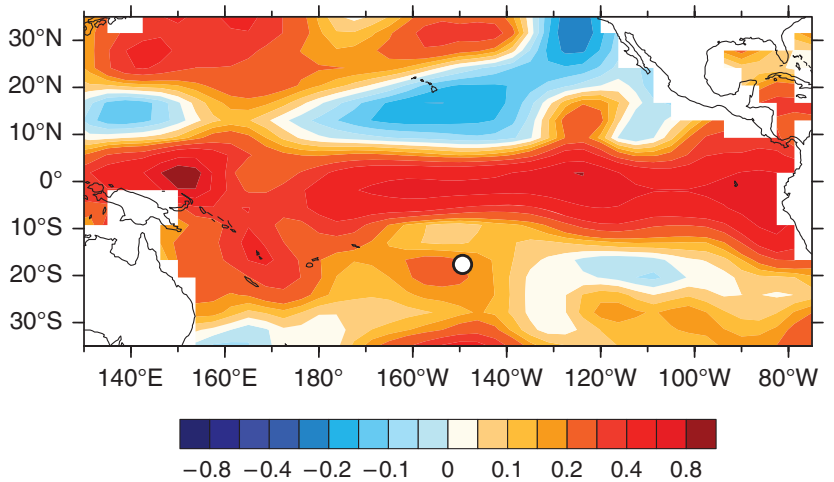

Figure 4 | Climate model results for Heinrich Stadial 1. Relative response of Pacific interannual SST variability for HS1 simulated by the coupled general circulation model CCSM3 (ref. 37). The difference between HS1 and modern climate relative to the latter is shown for the standard deviation (s.d.) of modelled monthly SST anomalies in the interannual EI Niño-Southern Oscillation band of CCSM3 (1.5-7 years). A value of 0.2 indicates a $20 \%$ higher s.d. of interannual SST anomalies during HS1 relative to modern conditions, for example, near Tahiti (white dot). A 78\% higher s.d. of interannual SST anomalies is indicated for the NINO3.4 region in the central equatorial Pacific $\left(170^{\circ}-120^{\circ} \mathrm{W}, 5^{\circ} \mathrm{N}-5^{\circ} \mathrm{S}\right)$. For the relevant areas in the equatorial Pacific and near Tahiti, the difference between the s.d. for HS1 and modern climate is statistically significant at the $90 \%$ level using an F-test (for details see Supplementary Fig. S12). Note the irregular contour interval.

in representing observed modern ENSO variability include a too narrow spatial SST maximum along the equator and a dominant $\sim 2$-year period instead of the observed 2-7 year band ${ }^{37,38}$. For Tahiti, the simulation indicates an $\sim 20 \%$ higher standard deviation of monthly SST anomalies in the interannual ENSO band relative to today (Fig. 4), which is similar to the coral-based estimate. Moreover, the simulation indicates an enhancement of interannual variability of the entire ENSO phenomenon during HS1, and identifies AMOC weakening under glacial boundary conditions as the cause $\mathrm{C}^{37}$. The AMOC weakening is associated with low SST anomalies in the tropical and subtropical North Atlantic. As a consequence, changes in the east-west SST gradient between the tropical Atlantic and Pacific induce an anomalous Walker circulation and positive trade-wind anomalies across Central and northern South America ${ }^{39,40}$. This atmospheric bridge leads to a weakened cross-equatorial SST contrast in the eastern tropical Pacific, accompanied by a weakening of the annual SST cycle in this region and increased interannual ENSO variability ${ }^{37}$, consistent with simulations under modern boundary conditions ${ }^{40-42}$. Whereas the simulation ${ }^{37}$ reproduces the increased interannual ENSO variability in Tahiti SST inferred from our HS1 coral, no conclusion can be drawn from the coral with respect to the simulated overall enhancement of ENSO variability during HS1. However, our coral-based results do not necessarily exclude a potential enhancement. Furthermore, the simulation suggests that the Tahiti cooling during HS1, inferred from mean coral Sr/Ca, is not a local feature, but forms part of a Pacific-scale cooling in response to glacial boundary conditions, which is consistent with SST reconstructions from Pacific sediments ${ }^{22-24}$ (Supplementary Fig. S9).

Our fossil coral drilled offshore Tahiti by IODP Expedition 310 indicates that significant interannual SST variability at typical ENSO periods occurred in the tropical South Pacific during HS1, an interval of the last glacial termination that was characterized by extreme cold conditions in the North Atlantic region and a weakening of the AMOC. This is different from today where the ENSO influence on Tahiti SST is weak. Our results suggest a greater ENSO influence in the South Pacific during HS1, related to a southward expansion or shift of ENSO SST anomalies. Our new coral record indicates that ENSO was operating and that interannual ENSO variability was pronounced during HS1. Clearly, more proxy records of interannual tropical Pacific SST variability and model simulations for this critical interval of the last glacial termination are necessary. Our evidence of tropical Pacific SST characteristics in an extreme climate of the past can help to constrain climate models for more reliable projections under future climate change.

\section{Methods}

Diagenetic investigations. The preservation of the fossil coral skeleton is comparable to a modern Tahiti Porites (Supplementary Figs S1 and S2). Encrusting microbialites were identified at the outer margin of the fossil coral as highdensity areas in X-radiographs. An unaffected area was selected for analysis and investigated using powder X-ray diffraction, petrographic thin sections and SEM. Five conventional X-ray diffraction analyses along the microsampling transect indicate $<0.5 \%$ calcite (the detection limit). Five petrographic thin sections and SEM analyses indicate excellent preservation of primary porosity, with no evidence for secondary aragonite or calcite cements (Supplementary Figs S3 and S4). Near the core top, SEM suggests slight skeletal dissolution and this section was rejected. In some areas, SEM reveals a slightly rougher skeletal surface compared with modern Tahiti Porites, probably representing very minor dissolution. The skeletal area identified as well preserved was used for microsampling, geochemical analyses and dating.

More than two hundred 15-20- $\mu \mathrm{m}$ diameter LA-ICP-MS analyses of polished coral pieces from a representative section of the microsampling transect also indicate no diagenetic cements. Pieces were vacuum impregnated with epoxy resin in a $25-\mathrm{mm}$ diameter round block. Once cured, the block was ground using $\mathrm{Al}$ oxide powder to obtain the desired cross section before the surface was finely polished with metallographic grinding paper followed by diamond pastes. Between polishing steps, blocks were briefly ultrasonically cleaned in Milli-Q $\mathrm{H}_{2} \mathrm{O}$ buffered with ammonium hydroxide to $\mathrm{pH} \sim 10$. Analyses were conducted at the University of Bremen using an Element 2 sector field ICP-MS in low-resolution mode, which was optimized for sensitivity, low oxide production $(\mathrm{ThO} / \mathrm{U}<0.5 \%)$, and element fractionation (U/Th 1.0-1.1) by ablation of a NIST 612 glass. LA was performed using a solid state $193 \mathrm{~nm}$ laser pulsed at $10 \mathrm{~Hz}$ with an irradiance of $\sim 0.6 \mathrm{GW} / \mathrm{cm}^{2}$ for $30-40 \mathrm{~s}$. The time-resolved signals (Supplementary Fig. S5) of ${ }^{24} \mathrm{Mg}$ and ${ }^{88} \mathrm{Sr}$ were background subtracted and internally standardized to ${ }^{43} \mathrm{Ca}$ to account for variations in ablation yield. Twenty seconds of signal from the period with the most stable $\mathrm{Sr} / \mathrm{Ca}$ ratio were filtered three times with a 2- $\sigma$ outlier rejection and averaged for each analysis. Calibration of measured element/Ca ratios was performed using a NIST 610 glass and COCAL calcite powder standard ${ }^{43}$. The precision of the LA-ICP-MS technique was estimated by repeat analysis of a pellet of the JCp-1 coral powder ${ }^{44}$ during each analytical session and was generally $<10$ and $<5 \%$ (s.d. of mean, $1 \sigma$ ) for $\mathrm{Mg} / \mathrm{Ca}$ and $\mathrm{Sr} / \mathrm{Ca}$ respectively. To allow direct comparison of the laser and solution data, laser-derived element/Ca ratios were adjusted by the amount required to match the mean of the laser analyses to that of the solution JCp-1 analyses. These adjustments were typically 0.2 and $0.4 \mathrm{mmol} \mathrm{mol}^{-1}$ for $\mathrm{Mg} / \mathrm{Ca}$ and $\mathrm{Sr} / \mathrm{Ca}$, respectively.

LA analyses were conducted across skeletal elements perpendicular to the centres of calcification (COCs). As previously observed in modern corals ${ }^{45}$, COCs are visible as dark patches in polished sections as they are slightly depressed and thus less polished and less reflective. After selecting a section with exposed COCs, a $50-\mu \mathrm{m}$ spot was scanned across the skeletal element to clean the surface, before a transect of 15-20 $\mu \mathrm{m}$ diameter spots was analysed along the pre-ablated track (Supplementary Fig. S6). A total of 36 transects were analysed along a 38-mm section of the fossil coral and the data are compiled in Supplementary Fig. S7. In contrast to previous studies of deglacial age fossil corals from Tahiti ${ }^{14,46}$, we found no pore fillings to attempt to analyse in our HS1 coral (Supplementary Fig. S6). Instead, we use values from the literature for the composition of secondary aragonite cements and altered $\mathrm{COCs}^{47,48}$ (Supplementary Fig. S7). Mg/Ca ratios are a particularly useful indicator of secondary aragonite and high-Mg calcite cements (for example, ref. 14). The $>200$ measurements clearly demonstrate the absence of secondary aragonite on this length scale. In fact, only one data point approaches the diagenetic aragonite field defined by ion probe studies of a similar length scale to our laser analyses ${ }^{47,48}$. The variability of the micron-scale measurements of our fossil coral compares well with that observed by ion probe and nanoSIMS studies of modern Porites corals ${ }^{45,49,50}$ suggesting the original high-resolution biomineralization signal is preserved.

Coral dating. U-Th analyses were performed using a VG-54 thermo-ionization mass spectrometer equipped with a $30-\mathrm{cm}$ electrostatic analyser and a pulsecounting Daly detector at CEREGE ${ }^{18,51}$. Two highly consistent U-Th ages of $15.006 \pm 0.065$ and $14.992 \pm 0.027 \mathrm{kyr}$ BP were determined on two aliquots of the fossil coral, indicating that the coral grew at $14.994 \pm 0.025 \mathrm{kyr} B P$ (ages are given relative to $\mathrm{AD} 1950)$. Initial $\left({ }^{234} \mathrm{U} /{ }^{238} \mathrm{U}\right)_{0}$ values are highly consistent with a 
mean value of $1.1453 \pm 0.0009(2 \sigma)$. This value is within the larger range adopted by the IntCal Group ${ }^{52}$ as isotopic screening criterion in the $0-17 \mathrm{kyr}$ interval $\left(\left({ }^{234} \mathrm{U} /{ }^{238} \mathrm{U}\right)_{0}=1.1452 \pm 0.0048,2 \sigma\right)$, as a necessary condition for closed system behaviour of U-series isotopes ${ }^{52}$ (Supplementary Table S1). Correction for detrita ${ }^{230} \mathrm{Th}$ is negligible because ${ }^{232} \mathrm{Th}$ concentrations were $<0.5$ p.p.b. Powder X-ray diffraction analyses conducted on three distinct slides for each aliquot using a method for detecting and quantifying very low calcite contents ${ }^{53}$ indicate $\leq 0.5 \%$ calcite. Two ${ }^{14} \mathrm{C}$ measurements at the coral's base and centre processed at Laboratoire de Mesure du Carbone 14 (Saclay, France) indicate ages of 15.072 \pm 0.130 and $14.964 \pm 0.178 \mathrm{cal} \mathrm{kyr} B P(1 \sigma)$, in excellent agreement with the U-Th age. Conven tional ${ }^{14} \mathrm{C}$ ages were converted to calibrated ages (cal kyr BP relative to AD 1950) using CALIB6.0 software ${ }^{54}$, the Marine09.14C dataset $^{55}$, a $\Delta \mathrm{R}=-100$ (ref. 56), an are reported as the midpoint of the $1 \sigma$ range. All data indicate good preservation of this coral and provide unquestionable chronological constraints on its growth period to be older than the onset of the Bølling warming.

Coral records. Microsampling of coral skeleton, $\delta^{18} \mathrm{O}$ analyses, chronology construction and monthly interpolation were carried out at the University of Bremen following established methods ${ }^{27}$. Using a $0.7-\mathrm{mm}$ diameter drill bit, an average of 26 samples per year were obtained from the fossil coral by continuous spotsampling along a single transect. For $\mathrm{Sr} / \mathrm{Ca}$ analyses a $0.20-0.32-\mathrm{mg}$ split of the sample powder that was used for $\delta^{18} \mathrm{O}$ analyses was dissolved in $7 \mathrm{ml} 2 \%$ suprapure $\mathrm{HNO}_{3}$ containing 1 p.p.m. Sc as internal standard. The Ca concentration of dissolved samples was 5-15 p.p.m. Measurements were performed on a Perkin-Elmer Optima 3300R simultaneous radial ICP-OES using a CETAC U5000-AT ultrasonic nebulizer at the University of Bremen. Element wavelengths were detected simultaneously in three replicates (Ca $317.933 \mathrm{~nm}, \mathrm{Ca} 422.673 \mathrm{~nm}$, Sr $421.552 \mathrm{~nm}, \mathrm{Sc} 361.383 \mathrm{~nm}, \mathrm{Mg} 280.271 \mathrm{~nm})$. Ca concentrations measured on an atomic line $(422.673 \mathrm{~nm})$ were averaged with the concentrations from an ionic line $(317.933 \mathrm{~nm})$ to compensate for possible sensitivity drift in a radial ICP-OES. Calibration standards were diluted from a master standard with a $\mathrm{Sr} / \mathrm{Ca}$ ratio of $9.099 \mathrm{mmol} \mathrm{mol}^{-1}$. A control standard set had Ca concentrations of 15 p.p.m. and varying $\mathrm{Sr}$ concentrations yielding $\mathrm{Sr} / \mathrm{Ca}$ ratios of $8.6-10 \mathrm{mmol} \mathrm{mol}^{-1}$. Measurements of a laboratory coral standard after each sample allowed offline correction for instrumental drift. Relative standard deviation of the $\mathrm{Sr} / \mathrm{Ca}$ determinations was better than $0.2 \%$. Nine aliquots of the Porites coral powder reference material JCp-1 (ref. 44) were treated like samples and the average $\mathrm{Sr} / \mathrm{Ca}$ value obtained during the course of this study was $8.924 \pm 0.014 \mathrm{mmol} \mathrm{mol}^{-1}$. The approximately fortnightly coral $\mathrm{Sr} / \mathrm{Ca}$ and $\delta^{18} \mathrm{O}$ records were filtered using a 2-point running mean, a common procedure for coral records with comparable resolution ${ }^{26,57}$. For chronology construction, annual Sr/Ca maxima were set to August (on average the coolest month) and annual Sr/Ca minima to March (on average the warmest month). The resulting records were interpolated to a monthly resolution for comparison with instrumental climate data and other coral records.

Proxy calibration. An average of $>17$ samples per year was obtained from our modern Porites coral (TAH-95) by continuous spot-sampling. Sr/Ca and $\delta^{18} \mathrm{O}$ analyses were performed at the University of Bremen following the same procedures as for the fossil coral. The seasonal maxima and minima in the $\mathrm{Sr} / \mathrm{Ca}$ record of the modern coral were tied to the corresponding extreme values in a monthly record of local SST (1986-1991) measured on the ocean side of the barrier reef ${ }^{31}$, $\sim 850 \mathrm{~m}$ from the coral site (Supplementary Fig. S8). A linear least-squares regression was then carried out for monthly interpolated Sr/Ca and monthly SST data (SST defined as independent variable), giving a relationship of:

$$
\mathrm{Sr} / \mathrm{Ca} \times 10^{3}=10.53( \pm 0.13)-0.057( \pm 0.005) \times \mathrm{SST}\left(r^{2}=0.69\right) .
$$

The same procedure was applied to the coral $\delta^{18} \mathrm{O}$ record, giving a relationship of:

$$
\delta^{18} \mathrm{O}=-0.2( \pm 0.3)-0.168( \pm 0.012) \times \operatorname{SST}\left(r^{2}=0.76\right) .
$$

Climate model simulations. The simulations with the Community Climate System Model (CCSM3), an ocean-atmosphere-sea ice-land surface general circulation model, are described in ref. 37. A present-day control simulation using the standard CCSM3 model set-up ${ }^{38}$ was performed. All simulations were carried out at Norddeutscher Verbund für Hoch- und Höchstleistungsrechnen (HLRN, Hannover, Germany).

\section{References}

1. Bard, E., Rostek, F., Turon, J.- L. \& Gendreau, S. Hydrological impact of Heinrich events in the subtropical Northeast Atlantic. Science 289, 1321-1324 (2000).

2. McManus, J. F., Francois, R., Gherardi, J. M., Keigwin, L. D. \& Brown-Leger, S. Collapse and rapid resumption of Atlantic meridional circulation linked to deglacial climate changes. Nature 428, 834-837 (2004).

3. Denton, G. H. et al. The last glacial termination. Science 328, 1652-1656 (2010).

4. Anderson, R. F. et al. Wind-driven upwelling in the Southern Ocean and the deglacial rise in atmospheric $\mathrm{CO}_{2}$. Science 323, 1443-1448 (2009)
5. Guilyardi, E. et al. Understanding El Niño in ocean-atmosphere general circulation models: progress and challenges. Bull. Am. Meteorol. Soc. 90, 325-340 (2009)

6. Collins, M. et al. The impact of global warming on the tropical Pacific Ocean and El Niño. Nat. Geosci. 3, 391-397 (2010).

7. Rein, B. et al. El Niño variability off Peru during the last 20,000 years. Paleoceanography 20, PA4003, doi:10.1029/2004PA001099 (2005).

8. Leduc, G., Vidal, L., Cartapanis, O. \& Bard, E. Modes of eastern equatorial Pacific thermocline variability: implications for ENSO dynamics over the last glacial period. Paleoceanography 24, PA3202, doi:10.1029/2008PA001701 (2009)

9. Tudhope, A. W. et al. Variability in the El Niño-Southern Oscillation through a glacial-interglacial cycle. Science 291, 1511-1517 (2001)

10. Beck, J. W. et al. Sea-surface temperature from coral skeletal strontium/calcium ratios. Science 257, 644-647 (1992)

11. Correge, T. et al. Interdecadal variation in the extent of South Pacific tropical waters during the Younger Dryas event. Nature 428, 927-929 (2004).

12. Asami, R. et al. Evidence for tropical South Pacific climate change during the Younger Dryas and the Bølling-Allerød from geochemical records of fossil Tahiti corals. Earth Planet. Sci. Lett. 288, 96-107 (2009).

13. DeLong, K. L., Quinn, T. M., Shen, C.- C. \& Lin, K. A snapshot of climate variability at Tahiti at $9.5 \mathrm{ka}$ using a fossil coral from IODP Expedition 310. Geochem. Geophys. Geosyst. 11, Q06005, doi:10.1029/2009GC002758 (2010).

14. Hathorne, E. C., Felis, T., James, R. H. \& Thomas, A. Laser ablation ICP-MS screening of corals for diagenetically affected areas applied to Tahiti corals from the last deglaciation. Geochim. Cosmochim. Acta 75, 1490-1506 (2011).

15. Trenberth, K. E. The definition of El Niño. Bull. Am. Meteorol. Soc. 78, 2771-2777 (1997).

16. Milne, G. A. \& Mitrovica, J. X. Searching for eustasy in deglacial sea-level histories. Quat. Sci. Rev. 27, 2292-2302 (2008).

17. Camoin, G. F., Iryu, Y. \& McInroy, D. B. \& the Expedition 310 Scientists. Proc. IODP, Vol. 310. (Integrated Ocean Drilling Program Management International, Inc.) doi:10.2204/iodp.proc.310.2007 (2007).

18. Deschamps, P. et al. Ice-sheet collapse and sea-level rise at the Bølling warming 14,600 years ago. Nature 483, 559-564 (2012)

19. Rasmussen, S. O. et al. A new Greenland ice core chronology for the last glacia termination. J. Geophys. Res. 111, D06102, doi:10.1029/2005JD006079 (2006).

20. Cahyarini, S. Y., Pfeiffer, M., Timm, O., Dullo, W.- C. \& Garbe-Schönberg, D. Reconstructing seawater $\delta^{18} \mathrm{O}$ from paired coral $\delta^{18} \mathrm{O}$ and $\mathrm{Sr} / \mathrm{Ca}$ ratios: methods, error analysis and problems, with examples from Tahiti (French Polynesia) and Timor (Indonesia). Geochim. Cosmochim. Acta 72, 2841-2853 (2008).

21. EPICA Community members. One-to-one coupling of glacial climate variability in Greenland and Antarctica. Nature 444, 195-198 (2006).

22. Stott, L., Timmermann, A. \& Thunell, R. Southern Hemisphere and deep-sea warming led deglacial atmospheric $\mathrm{CO}_{2}$ rise and tropical warming. Science 318, 435-438 (2007)

23. Kienast, M. et al. Eastern Pacific cooling and Atlantic overturning circulation during the last deglaciation. Nature 443, 846-849 (2006).

24. Koutavas, A. \& Sachs, J. P. Northern timing of deglaciation in the eastern equatorial Pacific from alkenone paleothermometry. Paleoceanography 23, PA4205, doi:10.1029/2008PA001593 (2008).

25. McCulloch, M. et al. High resolution windows into early Holocene climate Sr/Ca coral records from the Huon Peninsula. Earth Planet. Sci. Lett. 138, 169-178 (1996)

26. Gagan, M. K. et al. Temperature and surface-ocean water balance of the mid-Holocene tropical western Pacific. Science 279, 1014-1018 (1998).

27. Felis, T. et al. Increased seasonality in Middle East temperatures during the last interglacial period. Nature 429, 164-168 (2004).

28. Linsley, B. K. et al. Tracking the extent of the South Pacific Convergence Zone since the early 1600s. Geochemistry, Geophysics, Geosystems 7, Q05003, doi:10.1029/2005GC001115 (2006).

29. Boiseau, M. et al. Atmospheric and oceanic evidences of El Niño-Southern Oscillation events in the south central Pacific Ocean from coral stable isotopic records over the last 137 years. Paleoceanography 13, 671-685 (1998).

30. Gouriou, Y. \& Delcroix, T. Seasonal and ENSO variations of sea surface salinity and temperature in the South Pacific Convergence Zone during 1976-2000. J. Geophys. Res. 107, 8011, doi:10.1029/2001JC000830 (2002).

31. Gerard, R. Station cotière de Tahiti, données brutes, 1979-1991. Rapport Centre ORSTOM de Tahiti, Archives d'Océanographie 92-06, 206 pp (1992).

32. Gagan, M. K., Dunbar, G. B. \& Suzuki, A. The effect of skeletal mass accumulation in Porites on coral Sr/Ca and $\delta^{18} \mathrm{O}$ paleothermometry. Paleoceanography 27, PA1203, doi:10.1029/2011PA002215 (2012).

33. Abram, N. J., McGregor, H. V., Gagan, M. K., Hantoro, W. S. \& Suwargadi, B. W. Oscillations in the southern extent of the Indo-Pacific Warm Pool during the mid-Holocene. Quat. Sci. Rev. 28, 2794-2803 (2009).

34. Stoll, H. M., Schrag, D. P. \& Clemens, S. C. Are seawater Sr/Ca variations preserved in Quaternary foraminifera? Geochim. Cosmochim. Acta 63, 3535-3547 (1999). 
35. Reynolds, R. W., Rayner, N. A., Smith, T. M., Stokes, D. C. \& Wang, W. An improved in situ and satellite SST analysis for climate. J. Clim. 15, 1609-1625 (2002).

36. Wittenberg, A. T. Are historical records sufficient to constrain ENSO simulations? Geophys. Res. Lett. 36, L12702, doi:10.1029/2009gl038710 (2009).

37. Merkel, U., Prange, M. \& Schulz, M. ENSO variability and teleconnections during glacial climates. Quat. Sci. Rev. 29, 86-100 (2010).

38. Yeager, S. G., Shields, C. A., Large, W. G. \& Hack, J. J. The low-resolution CCSM3. J. Clim. 19, 2545-2566 (2006).

39. Wang, C. An overlooked feature of tropical climate: Inter-Pacific-Atlantic variability. Geophys. Res. Lett. 33, L12702, doi:10.1029/2006GL026324 (2006).

40. Timmermann, A. et al. The influence of a weakening of the Atlantic Meridional Overturning Circulation on ENSO. J. Clim. 20, 4899-4919 (2007).

41. Xie, S.- P. On the genesis of the equatorial annual cycle. J. Clim. 7, 2008-2013 (1994).

42. Guilyardi, E. El Niño-mean state-seasonal cycle interactions in a multi-model ensemble. Clim. Dyn. 26, 329-348 (2006).

43. Hathorne, E. C., James, R. H., Savage, P. \& Alard, O. Physical and chemica characteristics of particles produced by laser ablation of biogenic calcium carbonate. J. Anal. At. Spectrom. 23, 240-243 (2008).

44. Okai, T., Suzuki, A., Kawahata, H., Terashima, S. \& Imai, N. Preparation of a new Geological Survey of Japan geochemical reference material: coral JCp-1. Geostandard. Newslett. 26, 95-99 (2002).

45. Cohen, A. L., Layne, G. D. \& Hart, S. R. Kinetic control of skeletal Sr/Ca in a symbiotic coral: implications for the paleotemperature proxy. Paleoceanography 16, 20-26 (2001)

46. Cohen, A. L. \& Hart, S. R. Deglacial sea surface temperatures of the western tropical Pacific: a new look at old coral. Paleoceanography 19, PA4031, doi:10.1029/2004PA001084 (2004).

47. Allison, N. et al. Reconstruction of deglacial sea surface temperatures in the tropical Pacific from selective analysis of a fossil coral. Geophys. Res. Lett. 32, L17609, doi:10.1029/2005GL023183 (2005).

48. Allison, N., Finch, A. A., Webster, J. M. \& Clague, D. A. Palaeoenvironmental records from fossil corals: the effects of submarine diagenesis on temperature and climate estimates. Geochim. Cosmochim. Acta 71, 4693-4703 (2007).

49. Allison, N. \& Finch, A. A. High temporal resolution $\mathrm{Mg} / \mathrm{Ca}$ and $\mathrm{Ba} / \mathrm{Ca}$ records in modern Porites lobata corals. Geochem. Geophys. Geosyst. 8, Q05001, doi:10.1029/2006GC001477 (2007)

50. Meibom, A. et al. Biological forcing controls the chemistry of reef-building coral skeleton. Geophys. Res. Lett. 34, L02601, doi:10.1029/2006GL028657 (2007).

51. Bard, E. et al. U/Th and ${ }^{14} \mathrm{C}$ ages of corals from Barbados and their use for calibrating the ${ }^{14} \mathrm{C}$ time scale beyond 9000 years BP. Nucl. Instr. Meth. B 52, 461-468 (1990).

52. Hughen, K. A. et al. Marine04 marine radiocarbon age calibration, 0-26 cal kyr BP. Radiocarbon 46, 1059-1086 (2004).

53. Sepulcre, S., Durand, N. \& Bard, E. Mineralogical determination of reef and periplatform carbonates: calibration and implications for paleoceanography and radiochronology. Global Planet. Change 66, 1-9 (2009).

54. Stuiver, M. \& Reimer, P. J. Extended ${ }^{14} \mathrm{C}$ data base and revised CALIB $3.0{ }^{14} \mathrm{C}$ calibration program. Radiocarbon 35, 215-230 (1993).

55. Reimer, P. J. et al. IntCal09 and Marine09 radiocarbon age calibration curves, 0-50,000 years cal BP. Radiocarbon 51, 1111-1150 (2009).
56. Bard, E., Arnold, M., Hamelin, B., Tisnerat-Laborde, N. \& Cabioch, G. Radiocarbon calibration by means of mass spectrometric Th-230/U-234 and C-14 ages of corals: an updated database including samples from Barbados, Mururoa and Tahiti. Radiocarbon 40, 1085-1092 (1998).

57. Abram, N. J. et al. Seasonal characteristics of the Indian Ocean Dipole during the Holocene epoch. Nature 445, 299-302 (2007).

58. North Greenland Ice Core Project members. High-resolution record of Northern Hemisphere climate extending into the last interglacial period. Nature 431, 147-151 (2004).

59. Barker, S. et al. Interhemispheric Atlantic seesaw response during the last deglaciation. Nature 457, 1097-1102 (2009)

60. Mann, M. E. \& Lees, J. M. Robust estimation of background noise and signal detection in climatic time series. Clim. Change 33, 409-445 (1996).

\section{Acknowledgements}

This research used samples provided by IODP, drilled on a mission-specific platform expedition conducted by the European Consortium for Ocean Research Drilling (ECORD) Science Operator (ESO). Funding was provided by Deutsche Forschungsgemeinschaft (DFG) (to T.F. and G.Wefer) and European Science Foundation (ESF) under EUROCORES Programme EuroMARC (to T.F.). Paleoclimate work at CEREGE is supported by Comer Science and Education Foundation, ESF (EuroMARC), European Community (Past4Future), Collège de France, and Institut de Recherche pour le Dèveloppement (IRD). E.C.H. was funded by a MARUM fellowship. We thank S. Pape for Sr/Ca and M. Segl for stable isotope analyses, K.-H. Baumann for SEM analyses, IODP Expedition 310 co-chiefs G. Camoin, Y. Iryu, staff scientist D. McInroy, 'DP Hunter' crew/drilling team and IODP Bremen Core Repository for support. We dedicate this manuscript to the memory of our friend and colleague Guy Cabioch who sadly passed away in October 2011

\section{Author contributions}

T.F. designed the study, generated coral geochemical time series, conceived data interpretation, and wrote the manuscript, R.A. is IODP Expedition 310 co-investigator, P.D., E.B. and N.D. performed coral dating and interpretation, E.C.H. performed LA-ICP-MS and U/Ca analyses and interpretation, M.K. performed Sr/Ca analyses, G.C. contributed a modern calibration coral and environmental data, U.M., M.Pr. and M.S. performed model analysis and interpretation, S.Y.C. and M.Pf. contributed information on modern coral records. All authors contributed towards the manuscript preparation

\section{Additional information}

Supplementary Information accompanies this paper at http://www.nature.com/ naturecommunications

Competing financial interests: The authors declare no competing financial interests.

Reprints and permission information is available online at http://npg.nature.com/ reprintsandpermissions/

How to cite this article: Felis T. et al. Pronounced interannual variability in tropical South Pacific temperatures during Heinrich Stadial 1. Nat. Commun. 3:965 doi: 10.1038/ncomms1973 (2012)

License: This work is licensed under a Creative Commons Attribution-NonCommercialNoDerivative Works 3.0 Unported License. To view a copy of this license, visit http:// creativecommons.org/licenses/by-nc-nd/3.0/ 